\title{
O Traço da Língua Pura
}

\section{Maria João Cantinho}

Resumo: Na obra de Walter Benjamin, a tradução não se resume apenas a um problema linguístico. É, antes de tudo, uma questão metafísica e que diz respeito ao poder mágico - no sentido benjaminiano - que a linguagem comporta em si. Este ensaio aborda precisamente a questão da tradução em Benjamin, enquanto possibilidade de despertar a centelha messiânica que percorre as línguas, que caminham para a Língua Pura. Que traço é esse? Para onde caminham as línguas, que sopro as anima?

Palavras-chave:Tradução, Messianismo, Linguagem

Os tradutores podem ser comparados a alcoviteiros diligentes que nos exaltam uma bela mulher semi-velada como altamente digna de amor, excitando em nós um irreprimível desejo de experimentar o original.

Goethe, Máximas e Reflexões, máxima 299, p. 75.

Ao arrepio de todas as concepções vigentes da linguagem e da tradução, Benjamin, logo nos primeiros anos da sua obra e desde muito jovem, aponta para uma outra compreensão da mesma, na esteira da concepção que o próprio Georg Hamann nos tinha legado, assim como o Primeiro Romantismo, que tão caro foi a Walter Benjamin. É no seio desta compreensão, onde confluem Hamann, Pré-Romantismo (Friedrich Schlegel e Novalis) e, ainda, Humboldt, que o jovem pensador desenvolverá um dos aspectos centrais da sua obra: a ideia de uma linguagem messiânica. Inúmeras são as interpretações da teoria benjaminiana, algumas remetendo mesmo para uma ligação com a cabala e com a teologia hebraica que, a meu ver, não se traduzem em clareza para a interpretação da mesma, mas antes lhe emprestam uma obscuridade que, de modo algum, favorece a nossa compreensão.

Se, no texto Sobre a Linguagem em Geral e Sobre a Linguagem humana, Benjamin nos explica que a linguagem humana é de outra ordem que a puramente comunicacional, a sua concepção da tradução (de 1923, aquando do texto A tarefa do Tradutor) insiste, de forma absolutamente coerente, na recusa da teoria da recepção, o que seria o equivalente - na tradução - à teoria da linguagem como pura comunicação. Por essa razão, se em 1915, com o seu texto Sobre a Linguagem em Geral e Sobre a Linguagem Humana, Walter Benjamin tinha já definido uma das pedras angulares do seu pensamento, com o texto A Tarefa do Tradutor oferece-nos o desenvolvimento da sua ideia inicial, insistindo no carácter messiânico da linguagem. Daí que o conceito de tradução, tal como ele o apresenta, ocupe uma posição absolutamente central ${ }^{1}$.

Pela leitura da carta de Benjamin, pressentimos que ele está ciente da importância do seu objecto de estudo e impaciente por desenvolvê-lo com amplitude. A razão não nos é 
estranha, pois o tema havia sido estudado por ele nos textos dos primeiros românticos, que viam na tradução um problema fundamental ${ }^{2}$. O seu estudo sobre o conceito de crítica permitira-lhe entrever a questão da tradução como um dos mais espinhosos problemas, mas, ao mesmo tempo, como uma porta de entrada para uma metafísica da linguagem. A própria leitura dos textos de Goethe, sobre a tradução, também havia despertado nele o desejo de reformular as tradicionais teorias da tradução, seguindo-lhe essa leitura na Tarefa do Tradutor.

Já no texto Sobre a linguagem em Geral e da linguagem humana, a linguagem é, para Benjamin, essencialmente tradução: "Todas as linguagens são traduzíveis umas nas outras. A tradução é a passagem de uma linguagem à outra por uma série de metamorfoses contínuas."3 Não é possível, no nosso entender, aceder a uma profunda compreensão d'A Tarefa do Tradutor sem articular a sua leitura com o texto Sobre a linguagem em Geral e da linguagem humana. Na verdade, é nas últimas páginas deste texto que o problema da tradução conhece as suas primeiras formulações, as quais serão, posteriormente, desenvolvidas. Se a natureza, na sua mudez, acede ao nome, tal acontece porque a linguagem inferior da natureza é traduzida numa linguagem superior ${ }^{4}$. E o que permite a tradução, no entender de Benjamin - relembre-se o final do texto da Sobre a linguagem, em que Walter Benjamin defende a ideia de que a nomeação é a tradução da linguagem das coisas - linguagem material - na linguagem do ser humano. E é necessário relembramos que é nela (nomeação) que é preciso encontrar o fundamento da tradução, isto é, "é necessário fundar o conceito de tradução no estrato mais profundo da teoria da linguagem". 5 É nesta passagem do texto que encontramos um elo de ligação entre a teoria da nomeação e a da tradução, o que nos permite concluir que a tradução transporta consigo o traço dos nomes.

Retome-se, agora, o texto A Tarefa do Tradutor, quando Benjamin afirma, logo no primeiro parágrafo:

A relação com o receptor, em lado nenhum se revela fecunda para o conhecimento de uma obra de arte ou de uma forma artística. E isto não só porque cada relação com um público determinado ou com o seu representante é um desvio, mas porque mesmo o conceito de um receptor "ideal" é prejudicial em todas as explicações teóricas sobre arte $[\ldots]^{6}$

Benjamin aponta-nos, desde logo, uma série de trilhos que devemos seguir, para um entendimento fecundo do seu texto. $\mathrm{O}$ facto de o autor partir de uma recusa da teoria da recepção dá-nos logo o mote: quer a obra quer a tradução não podem ser definidas em termos de comunicação. Também a teoria da recepção da obra insistia neste aspecto: a questão da comunicação. Daquele ponto de vista - e não aos olhos de Benjamin - "a linguagem é um instrumento de comunicação, a obra é uma comunicação, uma mensagem e a tradução a transmissão interlinguística desta comunicação. Assim, certos teóricos fazem da tradução a «comunicação de uma comunicação»"7.

A Tarefa do Tradutor coloca-se nos antípodas desta posição, da mesma forma que Benjamin já se posicionara contra a teoria da linguagem instrumental, no ensaio Sobre a Linguagem. A coerência do percurso benjaminiano, insistindo na ideia de uma teoria da linguagem, adivinha-se claramente aqui, logo no início do texto. E é justamente nesse sentido que ele caminha, quando afirma, no mesmo parágrafo: "nenhum poema vale para o leitor, nenhum quadro para o espectador, nenhuma sinfonia para o auditório". De forma alguma isso significa que o autor seja alheio à sua recepção, mas sim, que a obra não é realizada em função de uma qualquer recepção. $O$ facto de uma obra depender do receptor, nesta posição, transforma-a, de imediato, em obra secundária. Ao mesmo 
tempo, na óptica de Benjamin - enquanto recusa da teoria da recepção - , ele faz valer a "pureza" da obra de arte (e da tradução) e a pureza da linguagem, aquela que não conhece a "subserviência" da comunicação.

Esta ideia encontra-se reiterada no segundo parágrafo:

Mas o que «diz» uma obra literária? Que comunica ela? Muito pouco, para quem a compreende. O que ela tem de essencial não é comunicação, não é mensagem. Uma tradução que, entretanto, procura transmitir não poderia transmitir senão a comunicação, e, portanto, qualquer coisa de não essencial. É, aliás, um dos sinais pelos quais se reconhece a má tradução. ${ }^{8}$

Este é o ponto de viragem no qual assenta o texto de Benjamin. Uma nova teoria da tradução que assenta, também, numa concepção da linguagem nomeadora (e nãoinstrumental). Se, como vimos no texto da linguagem, a comunicação era um abastardamento da essência da linguagem, então, uma teoria da tradução que assenta sobre uma perspectiva meramente comunicativa reflecte em si a decadência da linguagem, a "queda" daquela, contaminando a própria tradução. E é precisamente neste sentido que se orienta o texto de Benjamin, pretendendo, assim, fundar uma nova teoria da tradução. Note-se, porém, que esta concepção da tradução não é meramente especulativa e teórica, mas ele visava responder verdadeiramente aos problemas que lhe eram colocados pela questão da tradução e procurar uma resposta que pudesse ser aplicada - o facto de o texto ser o prefácio de uma tradução que ele próprio levou a cabo revela esse desejo.

Mas o que é, então, a tradução? "A tradução é uma forma [sublinhado nosso]. Concebê-la como tal implica retornar ao original. Porque no original está a lei da sua forma, enquanto contida na sua traduzibilidade." ${ }^{9}$ O que entende Benjamin por «forma»? Estará ele a dizer-nos que a tradução literária é uma forma literária? Parece-nos que não é esse exactamente o sentido das suas palavras. Encontramos nesta passagem o eco das palavras dos Primeiros Românticos (Friedrich Schlegel e Novalis) ${ }^{10}$ e Goethe, na sua procura obstinada de um modelo que explicasse a metamorfose das plantas ${ }^{11}$, o qual seria identificado na formulação da ideia de Planta Originária [Urpflanze $]^{12}$. A tradução para Benjamin - é um certo tipo de organismo, regida, como ele próprio o diz, por um princípio de organização, isto é, uma lei. E é justamente esta lei que se constitui como a sua condição de possibilidade.

Tal como o entendia Goethe, ao dizer que a Urpflanze continha em si a lei da metamorfose, também o original da obra contém em si - é-lhe imanente - a lei é a traduzibilidade do original ${ }^{13}$. É, assim, o original "que contém a lei desta forma". É nela que se oculta o segredo da sua traduzibilidade [Übersetzbarkeit], isto é, do seu desenvolvimento interno, na travessia para uma outra língua que lhe é estrangeira.

Neste sentido, o original é a forma primeira que pode engendrar a tradução ${ }^{14}$. É matriz, mas é também forma que contém a lei - a traduzibilidade - do seu desenvolvimento posterior, isto é, da vida da obra. Quando dizemos "que certas obras são, por essência, traduzíveis, isso não significa que a tradução é essencial para elas, mas sim que a sua traduzibilidade [...] é imanente aos originais" ${ }^{15}$.

Por melhor que uma tradução seja, não pode nunca significar algo para o original. Porém, original e tradução ligam-se por uma "correlação de vida"16, uma correlação que é tanto mais íntima (innig) ${ }^{17}$ para o original quanto já não tem significação, isto é, quando ela "já nada significa para o original". Ela é puramente autónoma e exterioriza-se na sua traduzibilidade. Se a tradução é uma «forma», então o domínio das formas é, à 
maneira goethiana, o das metamorfoses, que se constituem como autotransformações da forma. Essa vida não existe senão na metamorfose. A tradução, de acordo com Benjamin, já nos aparece no texto Sobre a Linguagem, como "a passagem de uma língua a outra por uma série de metamorfoses contínuas" ${ }^{18}$.

Assim, dizer que a tradução é uma «forma» é afirmar que ela é uma certa metamorfose do original - e não uma transformação exterior à obra. E o princípio pela qual ela passa da obra à tradução é a sua «traduzibilidade», como vimos. Benjamin está, aqui, a pensar numa traduzibilidade radical e absoluta, que é própria da obra.

Mesmo que as obras não tenham sido, ainda, traduzidas, o facto de a tradução ser uma forma - que implica metamorfose e passagem -, "a traduzibilidade deve ser essencial a certas obras." ${ }^{19}$ Faz parte do próprio movimento essencial à vida da obra. É a traduzibilidade do original, essa lei secreta do seu desenvolvimento, que estabelece a mais estreita relação entre o original e a tradução.

O espaço da tradução é, assim, o da vida da obra. Não se trata da vida no sentido puramente biológico, mas na vida enquanto historicidade da obra, tomada, não como um puro movimento de mudanças lineares e contínuas, mas como um processo de metamorfoses e de passagens, que engendram o desenvolvimento da obra. É preciso pensar a «vida da obra» como uma dimensão que não é redutível ao ciclo prédeterminado e puramente instintivo, mas sim que pertence à própria história das obras e das línguas. É esta dimensão, a da vida histórica da obra, que Benjamin coloca precisamente como suposto da tradução. Longe de se limitar à comunicação de um conteúdo de significações numa língua estrangeira, a tradução exprime "a relação mais íntima entre as línguas" ${ }^{20}$. Esta relação de intimidade entre as línguas, com a qual se confronta o tradutor, não se torna possível senão existir entre elas uma «convergência original» [eigentümlichen Konvergenz] ${ }^{21}$ :

Aquela relação íntima pensada entre as línguas é a de uma convergência particular. Ela consiste no facto de as línguas não serem estrangeiras umas às outras, sendo aparentadas naquilo que querem dizer e isto a priori. ${ }^{22}$

Se, por um lado, a tradução é apresentação [Darstellung] $]^{23}$ da obra, fazendo descobrir a pertença recíproca entre o original e a própria tradução, descobrindo, pela traduzibilidade, a «vida histórica» do original, por outro, ela é também a descoberta de uma relação, de um parentesco entre as línguas ${ }^{24}$, no sentido em que elas apresentam em si um ponto de convergência. Há um «querer-dizer» [Das Meinen]. Anuncia-se, neste ponto, a tensão simbólica que unifica as línguas e que constitui o ponto fulcral da análise do problema essencial da tradução.

É, precisamente, este apontar para um "ponto comum" que, secretamente, age no interior das línguas e as faz elevar acima da sua condição dispersa. A finalidade da tradução é, precisamente, a apresentação desse «comum» que se esconde nas línguas, quer-se como a revelação da relação entre as línguas, isto é, entre a língua tradutora e a língua traduzida. Neste sentido, a tradução é dupla na sua operacionalidade: como tradução das obras e tradução das línguas - descoberta da sua relação de intimidade.

Do ponto de vista histórico, as línguas são aparentadas, ou por filiação ou, então, por contacto. Estabelecem-se entre elas relações de semelhança, certamente, as línguas tocam-se, mas o que Benjamin quer dizer, na verdade, é que "as línguas são parentes $a$ priori, ou seja, elas são aparentadas ontologicamente, naquilo que elas 'querem-dizer'". É aqui que Benjamin se afasta, também, das teorias tradicionais da tradução. Se a teoria tradicional assenta sobre o "parentesco linguístico", produzido pela «semelhança», 
Benjamin desfaz este equívoco, mostrando que o "parentesco linguístico" existe, mas ele funda-se sobre um outro parentesco, que é de ordem ontológica: o "querer-dizer" das línguas, aquilo que nelas ressuma, como o seu mais secreto anseio.

No entanto, ainda que não se possa produzir esta relação de intimidade entre as línguas, pode-se «apresentá-la». Ao mesmo tempo, ao apresentar esta relação de intimidade entre as línguas, cumpre uma outra dimensão, que lhe é subjacente: apresenta a vida da obra, no seu sentido histórico, a sua vida superior Überleben, permitindo que a obra ultrapasse a finitude da sua língua para aceder a uma linguagem superior - a Língua Pura. Neste sentido, a tradução salva a obra, assegurando-lhe uma vida póstuma.

\section{O parentesco secreto das línguas}

Comecemos pela advertência de Benjamin: "Se, na tradução, o parentesco das línguas se anuncia, é completamente diferente da vaga semelhança entre o original e a sua reprodução [Nachbildung]"25. O parentesco de que Benjamin nos fala não é o da "semelhança". Por outro lado, ele afasta também o parentesco fundado sobre uma origem comum das línguas.

O parentesco das línguas é "histórico". Como, por exemplo, o parentesco entre as línguas latinas, entre si, o que lhes dá um "ar de família". Mas ainda não é nesse parentesco que Benjamin está a pensar e sim num parentesco "supra-histórico" [überhistorische]:

Qualquer parentesco supra-histórico consiste, antes, no facto de, em cada uma delas, enquanto uma totalidade, se querer dizer o mesmo; isto não é alcançável, todavia, por nenhuma delas isoladamente, mas unicamente na totalidade das intenções que se completam umas às outras: na língua pura [die reine Sprache $]^{26}$.

Eis-nos no coração da expressão central da Tarefa do Tradutor, a língua pura [die reine Sprache]. Foco de todas as línguas, é precisamente a língua pura que todas as línguas "querem-dizer". É, precisamente, neste "ponto focal" (Brennpunkt) ${ }^{27}$ que todas as línguas convergem:

Nas línguas tomadas uma a uma e, portanto, incompletas, o que elas querem dizer não pode nunca ser atingido de maneira relativamente autónoma, como nas palavras ou nas frases tomadas separadamente, mas é submetido a uma metamorfose constante, até que ressalte, como língua pura, da harmonia de todos os modos do querer-dizer. ${ }^{28}$

O "querer-dizer", ou melhor, o que cada língua quer dizer [meint], remete-nos para o que é ansiado, algo que percorre a língua como um sopro. E este querer-dizer único, que existe em todas as línguas, de forma oculta e à espera de emergir da "harmonia de todas as línguas" é precisamente o que Benjamin chama "o fim messiânico da sua história"29. Abre-se, assim, a possibilidade messiânica enquanto a tarefa do tradutor, por excelência:

Mas se estas (as línguas) crescerem até ao fim messiânico da sua história, então é a tradução que se inflama [entzündet]na eterna persistência vital das obras [Fortleben der Werke] e no renascer infinito [Aufleben] das línguas, que há de sempre, de cada vez, pôr à prova o santo crescimento das línguas[...]. ${ }^{30}$ 
A tradução inflama-se pela persistência vital das obras e no renascer infinito das línguas. É preciso notar esta vida infinitamente renascente das línguas se manifesta na vida continuada das obras. Eles aparecem intimamente entrelaçados. É na medida em que a tradução é o pôr à prova da vida das línguas que ela toma sobre si um saber: o da proximidade da língua pura, que amadurece nas línguas.

É na passagem que vem a seguir que nós encontramos uma relação com a questão da Revelação. Se a tradução apresenta o parentesco das línguas, se é ela que atesta o "santo crescimento" das línguas, ela mediatiza um outro crescimento que é o das "religiões":

Em qualquer dos casos, é de admitir que qualquer tradução é apenas um modo efémero de nos confrontarmos com a estranheza das línguas. Permanece negada ao homem uma solução desta estranheza que não seja temporal e provisória, não lhe é permitida uma solução instantânea e definitiva ou, pelo menos, ele não pode aspirar a ela directamente. Indirectamente, no entanto, consegue-o o crescimento das religiões, que amadurece nas línguas a semente escondida de uma língua mais elevada. [...] Nela (na tradução) o original ascende por assim dizer a uma atmosfera da língua mais elevada e pura[... $]^{31}$.

Quando Benjamin fala de religião, neste contexto, está a referir-se à "religião revelada". A dimensão da Revelação é, assim, constitutiva na linguagem, isto é, "cumprese na linguagem". Cada língua transporta em si um "querer-dizer" que é da ordem da Revelação, também. A vida da religião está, por um lado, ligada ao comentário, mas também à tradução, como a tarefa de levar a cabo um crescimento das próprias religiões. É visível, em Benjamin, desde muito cedo, a preocupação de Benjamin, relativamente às questões da tradução e do comentário, a reflexão, também, sobre a questão da Revelação ${ }^{32}$. E a tradução, como o sabe bem Benjamin, é um acto essencial na vida da religião, precisamente pela tradução dos textos religiosos ${ }^{33}$. A palavra da Revelação não pode habitar somente uma língua, necessitando, para isso, da passagem entre as várias línguas, como "pontes secretas", que fazem passar a palavra da Revelação.

Assim, se adivinha também a possibilidade da redenção messiânica das línguas prolíferas. A tensão do "querer-dizer” perpassa nelas como o seu sopro vital, exprimindo a tensão das línguas, numa tensão para a língua pura:

Permanece em toda a linguagem[...], fora do comunicável, um incomunicável, qualquer coisa que, segundo o contexto onde se desenvolve, é simbolizante ou simbolizado. Simbolizante somente nas obras acabadas da linguagem; mas simbolizado no próprio devir das línguas. E o que procura representar-se e instaurar-se no devir das línguas, é o núcleo da língua pura. ${ }^{34}$

O "querer-dizer [das Meinen]" e também o modo de querer dizer reenvia sempre e inevitavelmente para a língua pura, não como um conceito finalista, mas como um anseio que se repete e se reactualiza, de modo constante, nas línguas, agindo nelas secretamente e a cada instante. Essa semente, aquilo que é "simbolizado" no próprio devir das línguas, é a língua pura. As línguas movem-se, assim, atraídas para a língua pura (é pois a tradução que apresenta e actualiza esse segredo) que nelas se oculta como um "incomunicável" porque simbolizado. Assim, as línguas visam o seu "repouso simbólico". Todas querem-dizer a língua pura, essa que já nada quer-dizer, que já nada quer comunicar. 
Para Benjamin, a multiplicidade das línguas aparece-lhe como fragmentação, daí que ele recorra à metáfora do vaso ${ }^{35}$, dizendo que cada língua é Bruchstück, isto é, fragmento. Enquanto tal, a multiplicidade das línguas reenvia a um todo, a uma língua "maior". Ainda que dissemelhantes, entre si, os "fragmentos" deste vaso podem-se completar (e harmonizar) até à formação do todo. Trata-se de procurar alcançar a "língua pura" que se encontra na língua à espera do seu pleno desenvolvimento. Paciente, exactamente como o fruto ou a flor, que esperam a maturidade plena.

A língua pura $^{36}$ não é uma categoria abstracta para Benjamin. É, pelo contrário, adâmica, nomeadora, como insistem Giorgio Agamben e, também, Antoine Berman - e a língua que há de $\operatorname{vir}^{37}$. Numa interpretação de $\operatorname{Berman}^{38}$, o autor insiste na relação benjaminiana entre a língua pura, como língua original, a língua de origem adâmica

A língua pura é aquela que não transmite conteúdos, que não é um meio de comunicação, a que conhece a mais plena dignidade. Poderíamos, ainda, expressar a formulação desse desejo, segundo as próprias palavras de Agamben: “[...] todas as línguas querem dizer a palavra que já não quer dizer" ${ }^{39}$. Aquilo que permanece de indizível nas línguas humanas, como nota a perspectiva de Agamben, o que não é dito ou o indizível, inscreve-se no querer-dizer das línguas, que é condição do devir das línguas. Porquê? Porque elas "movem-se" para a língua pura como o seu anseio mais luminoso, aquela em que a palavra é não-expressiva ${ }^{40}$ (ausdrucksloses Wort): “[...]Nesta linguagem pura que não visa mais nada nem exprime mais nada, mas é palavra não-expressiva e criadora, aquilo que é visado em todas as línguas"41.

O tradutor deve, assim, tentar trazer para a sua língua o eco da língua da qual ele traduz, vinculado ao trabalho da "restauração" da língua pura, despertando-a. Numa carta a Scholem, a propósito da tradução de Píndaro, levada a cabo por Hölderlin, fala mesmo do amor de Hölderlin pelo acto de traduzir ${ }^{42}$. A tarefa do tradutor é, assim, uma tarefa "amorosa"43, no sentido em que luta por salvar a língua, por amor e fidelidade às mesmas. Longe de aplanar as diferenças entre as línguas, a tradução mede-se por aquilo que as torna as línguas estrangeiras umas às outras e converte-se numa tarefa infinita, que busca resgatar a semente da língua pura que nelas ressoa, isto é, "a semente latente de uma linguagem superior" 44 . Longe de ser uma traição do original, salva-o e permite que ele se eleve a uma atmosfera "mais pura e mais alta da linguagem" [höheren und reineren Luftkreis der Sprache $]^{45}$, esforçando-se por caminhar para "o reino prometido e interdito onde as línguas se reconciliarão [Versöhnung] e se cumprirão [Erfüllung]"46. É, com efeito, para esta tarefa que constitui o trabalho do tradutor, que, pelo seu trabalho, leva a cabo a apresentação da língua pura, "fazendo amadurecer, na tradução, a semente da pura linguagem" ${ }^{47}$. Na verdade, Benjamin remete-nos aqui para uma concepção platónica da linguagem, pois o Logos que a filosofia pretende alcançar é mais "alto" e mais "puro" que a linguagem natural.

Para Benjamin, a tradução é o anúncio do "termo messiânico" do desenvolvimento histórico das línguas e é aquilo que as impele, não só para a sua libertação da função da comunicação, como também as impele para a reconciliação final, através da língua pura. Estaremos aqui diante da linguagem como promessa, tal como ele a define, como "ideia da prosa"? Da linguagem que "convém" ao "mundo messiânico" como "mundo da actualidade integral"? ${ }^{48}$ No texto A Tarefa do Tradutor ouvimos um apelo secreto ou um canto "que cresce nas línguas" e que aponta para uma unidade, que é da promessa messiânica da linguagem, aquela que visa a restauração da língua nomeadora e libertação final das línguas.

Benjamin viu nas "vertiginosas" traduções de Hölderlin, sobretudo as das tragédias de Sófocles, a confirmação da sua tese. Aí, como ele próprio o diz, "A harmonia das línguas 
é tão profunda que o sentido só é tocado pela língua como uma harpa eólica pelo vento." ${ }^{49}$ Arquétipo ou modelo de toda a tradução, ela encerra, no entanto, um "o tremendo e originário perigo de qualquer tradução: que os portões de uma língua, tão alargada e bem dominada acabem por se fechar, encerrando o tradutor no seu silêncio. As versões de Sófocles foram as últimas obras de Hölderlin. Nelas o sentido precipita-se de abismo em abismo, até ameaçar perder-se nas profundezas insondáveis da língua." 50

Maria Filomena Molder fala desse "perigo sublime a que está exposto aquele que traduz"51. Não se trata do perigo de "regressar à confusão babélica", mas antes "o de sofrer a vertigem do transumanar sem qualquer protecção: subitamente embriagar-se na audição de todas as vozes quase em uníssono, afundando-se nelas." 52 E perder-se para sempre. É também o perigo daquele que, por amar demais, pode sucumbir à vertigem do seu desejo. Sem ponto de retorno, ao seguir o traço da língua.

Abstract: At Benjamin's work, the conception of translation is not only a linguistic problem. It's more a question of Metaphysics and related with the magical power - in a benjaminian's meaning - of the human language. This essay addresses the question of the translation, as a possibility of awaking the messianic spark that runs through the languages. What kind of trace is that? To go where the languages, what kind of wind animates them?

Keywords: Translation, Messianism, Language

\section{Referências Bibliográficas}

BENJAMIN, WALTER, Gesammelte schriften, Tomo II e IV, unter Mitwirkung von Theodor Adorno und G. Scholem, hrsg. von Rolf Tiedemann und Hermann Schweppenhaüser (tomo com o concurso respectivamente de Hella Tiedemann-Barthels e Tilmann Rexroth), Suhrkamp Verlag, Frankfurt am Main, 1972-1990.

BENJAMIN, WALTER, Briefe I,II, herausgegeben und mit Anmerkungen versehen von Gershom Scholem und Theodor Adorno, Suhrkamp Verlag, Frankfurt, 1966.

AGAMBEN, GIORGIO, "Langue et Histoire. Catégories historiques et catégories linguistiques dans la pensée de Walter Benjamin", trad. do italiano por Yves Hersant, in Walter Benjamin et Paris, Colloque international 27 - 29 juin 1983, Éditions du Cerf, Paris, 1986.

BERMAN, ANTOINE, L'Épreuve de l'Étranger, Édition Flammarion, Paris, 1995.

BERMAN, ANTOINE, L'Âge de la Traduction, «La Tache du Traducteur» de Walter Benjamin, un commentaire, Texte établi par Isabelle Berman avec la collaboration de Valentina Sommella, col. Intempestives, Presses Universitaires de Vincennes, Paris, 2008.

GAGNEBIN, JEANNE MARIE, Histoire et narration chez Walter Benjamin, Ed. L'Harmattan, Paris, 1994.

FENVES, PETER, Arresting Language: From Leibniz to Benjamin, Stanford University Press, Stanford, 2001. 
GOETHE, A Metamorfose das Plantas [Die Metamorphose der Pflanzen], Tradução, Introdução, notas e apêndice de Maria Filomena Molder, Col. Estudos Gerais, Série Universitária, Clássicos de Filosofia, Imprensa Nacional-Casa da Moeda, Lisboa, 1993. GOETHE, Obras Completas, tradução de João Barrento, Relógio d'Água, Lisboa, 2000. GOETHE, A Metamorfose das Plantas [Die Metamorphose der Pflanzen], Tradução, Introdução, notas e apêndice de Maria Filomena Molder, Col. Estudos Gerais, Série Universitária, Clássicos de Filosofia, Imprensa Nacional-Casa da Moeda, Lisboa, 1993. GOETHE, Obras Completas, tradução de João Barrento, Relógio d'Água, Lisboa, 2000. Hamann, JOHANN G., Aesthetica in Nuce, Metacritique du Purisme de la Raison Pure, Vrin, Paris, 2001.

JUSTO, JOSÉ M., Organizador e autor da introdução de Ergon ou Energeia, filosofia da linguagem na Alemanha, secs. XVIII e XIX, editora apáginastantas, trad. de Lídia campos Rodrigues e Rosa Maria Sequeira e José M. Justo, Materiais Críticos -7, Lisboa, 1986.

MENNINGHAUS, Winfried, Walter Benjamins Theorie der Sprachemagie, Suhrkamp Verlag, Frankfurt, 1980.

MOLDER, MARIA FILOMENA, "Três Motes para o Pensamento Morfológico de Goethe”, in Análise, nº 17, edições Colibri, Lisboa, 1994, 161/197.

MOLDER, MARIA FILOMENA, O Pensamento Morfológico de Goethe, Estudos Gerais- Série Universitária, Imprensa Nacional - Casa da Moeda, Lisboa, 1995.

MOLDER, MARIA FILOMENA, Semear na Neve, editora Relógio d'água, Lisboa, 1999.

MOLDER, MARIA FILOMENA, O Absoluto que pertence à Terra, ed. Vendaval, Lisboa, 2005.

SCHOLEM, GERSHOM, Le Nom et les symboles de Dieu dans la mystique juive, trad. M. R. Hayoun et G.Vajda, éd. du Cerf, Paris, 1983.

SELIGMANN-SILVA, MÁRCIO (org.), Leituras de Walter Benjamin, Annablume, S.Paulo, 1999.

SELIGMANN-SILVA, MÁRCIO, Ler o Livro do Mundo, Walter Benjamin: romantismo e Crítica Poética, Iluminuras, S. Paulo, 1999.

SELIGMANN-SILVA, MÁRCIO, O Local da diferença, editora 34, S.Paulo, 2005.

\section{Notas}

${ }^{1}$ Cf. Briefe, I, p. 259, numa carta redigida a Scholem, datada de 26 de Março de 1921, por altura da redacção do texto: "Neste momento, encontro-me dividido entre muitos trabalhos, do qual um tenho a certeza, interessar-vos-á ao mais alto grau, «A Tarefa do Tradutor». (...) Mas trata-se de um objecto que, para mim, ocupa uma posição de tal maneira central que eu ignoro, ainda, se, no estado actual do meu pensamento, eu posso desenvolvê-lo com suficiente liberdade(...)". (Tradução minha).

${ }^{2}$ Cf. o próprio texto de Benjamin, A Origem do Conceito de Crítica de Arte no Romantismo Alemão. Ver, ainda, a este propósito consultar a obra de ANTOINE BERMAN, L'Épreuve de l'Étranger, como também PETER SZONDI, Pétique de l'Idéalisme Allemand.

${ }^{3}$ G.S., II, 1, pp. 150, 151 . 
${ }^{4}$ G.S., II, 1, p. 157: "Toda a linguagem superior é tradução da linguagem inferior (...)".

${ }^{5}$ G.S., II, 1, p. 151.

${ }^{6}$ Tradução de Maria Filomena Molder, ainda não publicada, de G.S., IV, 1, p. 9.

${ }^{7}$ ANTOINE BERMAN, L'Âge de la Traduction, col. intempestives, ed. Presses Universitaires de Vincennes, Paris, 2008, p. 47.

${ }^{8}$ G.S., IV,1, p. 9.

${ }^{9}$ G.S., IV, 1, p. 9: "Übersetzung ist eine Forme. Sie als solche zu erfassen, gilt es zurückzugehen auf das Original. Denn ihm liegt deren Gesetz als dessen Übersetzbarkeit beschlossen."

10 Já anteriormente, quando referimos os conceitos que marcaram, nos Primeiros Românticos, o pensamento benjaminiano, referimos os conceitos de traduzibilidade e de criticabilidade da obra.

${ }^{11}$ Cf. Goethe, Metamorfose das Plantas, tradução de Maria Filomena Molder, Imprensa Nacional-Casa da Moeda, Lisboa, 1993.

12 Todavia, como M.F.M. o afirma na introdução, p. 23, o tema da Urpflanze não foi formulado senão na sua correspondência e em escritos de carácter autobiográfico, particularmente na obra Viagem a Itália. Sem querer alongar-me em considerações sobre um tema que é objecto de uma análise profunda e exaustiva de Maria Filomena Molder, remeto para a sua obra $O$ Pensamento Morfológico de Goethe, Imprensa Nacional-Casa da Moeda, Estudos Gerais, Série Universitária, Lisboa, 1995. Mas ressalto a seguinte definição, que se nos afigura, aqui, oportuna e pertinente, p. 153: "a Urpflanze designa precisamente e de modo simultâneo a forma, enquanto origem de todas as configurações possíveis de plantas e enquanto possibilidade da sua identificação".

${ }^{13}$ Veja-se, ainda, o ensaio de MARIA FILOMENA MOLDER, "A interrupção catastrófica da Tradução: A Torre de Babel", O Absoluto que Pertence à Terra, editora Vendaval, 2005, pp. 85-125.

14 Porém, o original também pode engendrar a crítica da obra, tal como Benjamin o reconheceu na sua obra $O$ Conceito de Crítica de Arte no Romantismo Alemão. Para estes aspectos, consultar as obras de ANTOINE BERMAN, L'épreuve de l'Étranger, Gallimard, Paris, 1984 e L'Âge de la Traduction, intempestives, Presses Universitaires de Vincennes, Paris, 2008.

${ }^{15}$ G.S., IV, 1, p. 11 .

${ }^{16} \mathrm{O}$ que Benjamin entende por vida é algo de muito peculiar. Quando ele fala de «forma» não está a referir-se a uma estrutura «formal», morta, petrificada (isso é algo que é da ordem do alegórico e se afasta profundamente da vida). O vivo é, para Benjamin, «forma», «metamorfose», tal como o entende o pensamento de Goethe. Cf. a este propósito o texto A Crítica da Violência.

${ }^{17}$ Como o nota Berman, L'Âge de la Traduction, pp. 72, 73, a palavra «innig» traduz-se por íntimo, tanto no francês como no português. Mas se, no português, essa palavra se conota com uma dimensão profundamente subjectiva, tal como no francês, no alemão ela reenvia a uma co-pertença dos seres que designa uma categoria mais lata e ontológica: Zusammenhang.

Esta palavra encontra-se na poesia de Hölderlin, quando ele diz «alles ist innig», e também na poesia de Rilke, quando ele fala de Innigkeit das coisas. Benjamin tem disso plena consciência. Assim, na óptica de Benjamin, a «intimidade entre o original e a tradução» trata-se, antes duma correlação ou duma co-pertença «natural». Esta ideia da 
pertença recíproca [Zusamenngehorigkeit], em Benjamin, é, aliás, desenvolvida no "Prefácio" à obra Origem, a propósito da relação entre a ideia/fenómeno. A apresentação [Darstellung] é precisamente a actividade do filósofo que permite compreender a pertença recíproca dos fenómenos à ideia, à maneira de uma constelação.

${ }^{18}$ G.S., II, l, p. 151.

${ }^{19}$ G.S., $I V, 1$, p. 10.

${ }^{20}$ G.S., $I V, 1$, p. 12.

${ }^{21}$ Esta convergência é original porque ela não equivale às convergências naturais - por exemplo, relações de «semelhança». Isto é, dois fenómenos podem ser ditos «convergentes» se eles se assemelham e se aproximam sobre o fundo da semelhança. Neste caso, Benjamin pensa a «convergência» a partir das diferenças entre as línguas.

${ }^{22}$ Idem.

${ }^{23}$ Idem, pp. 11, 12.

${ }^{24}$ Idem, p. 12

${ }^{25}$ G.S., IV, 1, p. 13.

${ }^{26}$ Idem.

${ }^{27} \mathrm{O}$ "ponto focal", termo utilizado por Goethe, embora seja hoje aplicado como conceito generalizado, tem a sua origem no estudo da óptica, podendo ser definido como uma área onde os raios luminosos que passam por um refractor se encontram mais próximos e proporcionam a possibilidade de formar uma imagem mais clara e definida. Cf. Materiais para o Estudo das Cores.

${ }^{28}$ G.S., IV, 1, p. 14.

${ }^{29}$ Idem, p. 14.

${ }^{30}$ Idem.

${ }^{31}$ G.S., IV, 1, p. 15 .

${ }^{32}$ Cf. carta de Benjamin a Scholem, datada de 22 de outubro de 1917, Briefe, I, p. 152. Numa passagem, ele diz: "Há no judaísmo o conceito de fé no sentido de um comportamento adequado à revelação?" Apesar de posterior a este texto da tradução, veja-se também a carta de Benjamin a Scholem, de 11 de Agosto de 1934, a propósito de Kafka e da sua relação com a Revelação (Briefe, II, p. 618).

${ }^{33}$ Como o diz Berman, L'Âge de la Traduction, pp. 128, 129, "todas as grandes traduções ocidentais têm um fundamento religioso, são obra religiosa (...) As traduções de Píndaro e de Sófocles por Hölderlin são religiosas. Como a tradução do Paraíso Perdido de Milton, por Chateaubriand ou Baudelaire por George. Religião, aqui, tem que ser tomada num sentido muito largo, como tudo o que tem relação à ligação do ser humano com a totalidade do mundo. Na medida em que toda a grande obra, sagrada ou profana, manifesta e, ao mesmo tempo, instaura esta ligação, na medida em que toda a grande obra é «religiosa», o acto da tradução também o é."

${ }^{34}$ G.S., $I V, 1$, p. 19.

${ }^{35}$ G.S., $I V, 1$, p. 18 .

36 Segundo Antoine Berman, Op. Cit., p. 115, se o termo "puro" nos remete imediatamente para a terminologia de Kant, do conhecimento puro, horizonte de pensamento de Benjamin nessa época, no entanto, o puro [rein] possui uma outra origem, que é Hölderlin, no qual toda a linguagem poética se funda na "pureza" [Reinheit]. Também no texto Sobre a Linguagem aparece o conceito de língua pura. 
${ }^{37}$ No seu texto, AgAmben também insiste nessa estrutura dupla, "Langue et Histoire", Walter Benjamin et Paris, pp. 796/798. A interpretação de Agamben faz coincidir o plano da língua pura com o da língua adâmica, cruzando a leitura dos textos Sobre a Linguagem com A Tarefa do Tradutor. Parece-nos que se trata, sobretudo, da categoria da língua que há de vir que aqui nos aparece em toda a sua plenitude, como uma "promessa das línguas" que abre o caminho à redenção messiânica.

${ }^{38}$ BERMAN, Op. Cit., p. 116.

${ }^{39}$ AgAmben, Op. Cit., p. 798.

${ }^{40}$ Parece surgir, aqui, alguma dificuldade, com a tradução da palavra. A palavra nãoexpressiva ou inexpressiva, de acordo com a tradução portuguesa, exige uma opção, sem que se deixe cair o leitor na ambiguidade do conceito.

${ }^{41}$ G.S.,IV, 1, p. 19.

${ }^{42}$ Briefe, I, p. 142.

${ }^{43}$ G.S., IV, 1, p. 18: "(...) a tradução deve, adoptar na sua própria língua, amorosamente e ao pormenor, o modo de visar o original, para tornar um e outro reconhecíveis, enquanto fragmentos de um mesmo vaso, como fragmentos de uma mesma língua maior."

${ }^{44}$ G.S., IV, 1, p. 15.

${ }^{45}$ Idem, pp. 14, 15.

${ }^{46}$ Idem, p. 15. Gostaríamos de referir, aqui, a proximidade e a relação desta ideia com a tese que aparece em Sobre o Conceito de História, o seu último texto, sobretudo nas teses que evocam a restituição messiânica dos nomes e a linguagem messiânica é, aí, considerada como "a prosa liberta que rompeu as cadeias da escrita". (Ms. 490).

${ }^{47}$ G.S., IV, 1, p. 17.

${ }^{48}$ G.S., I, 3, 1239.

${ }^{49}$ G.S., $I V, 1$, p. 21.

${ }^{50}$ G.S., $I V$, 1, p. 21.

${ }^{51}$ Cf. Molder, Maria Filomena, O Absoluto que pertence à Terra, in "A Interrupção Catastrófica da Tradução: A Torre de Babel", p. 89.

${ }^{52}$ Idem. 